Article

\title{
Short Food Supply Chains (SFSC) as Local and Sustainable Systems
}

\author{
Sebastian Jarzębowski ${ }^{1, *}$, Michael Bourlakis ${ }^{2}$ and Agnieszka Bezat-Jarzębowska ${ }^{3}$ \\ 1 Logistics \& Procurement Centre, Kozminski University, 03-301 Warsaw, Poland \\ 2 Centre of Logistics, Procurement \& Supply Chain Management, Cranfield School of Management, \\ Cranfield University, Cranfield, Bedford MK43 0AL, UK; m.bourlakis@cranfield.ac.uk \\ 3 Institute of Agriculture and Food Economics-National Research Institute, 00-002 Warsaw, Poland; \\ Agnieszka.Bezat-Jarzebowska@ierigz.waw.pl \\ * Correspondence: sjarzebowski@kozminski.edu.pl
}

Received: 5 March 2020; Accepted: 4 June 2020; Published: 9 June 2020

\begin{abstract}
We distinguish different types of Short Food Supply Chains (SFSC); nevertheless, their common main characteristic relate to reduced numbers of intermediaries between farmers/food producers and consumers. The aim of the paper is to present the SFSCs as local and sustainable food systems with their possible development. The SFSC idea follows the concept of sustainability, which is based on three pillars: environmental, social, and economic. In the paper, the authors also highlight other barriers to growth, and challenges faced by local food systems.
\end{abstract}

Keywords: short supply chain; sustainability; local food systems; economic; environmental and social dimension

\section{Introduction}

Nowadays, we observe that food supply chains, and in general agribusiness systems, are transformed into a coordinated food system [1]. This leads to competition not only between individual companies in a food chain but also to competition between supply chains and networks $[2,3]$. As a result of these trends, research on developing new models for food markets is required. We observe a continuous increase of consumers' demand on food safety and its functionality [4]. In addition, consumers require product diversity, higher packaging quality, and the quality of services [4]. A further argument for intensive research on this topic, which is recognized by the scientists, is the importance of supply chain management due to instability of products and weak product flow tracking [5].

Therefore, it is obvious that food producing systems must be operated in a sustainable way [6]. The protection of environment and the economy of sustainable development is nowadays the most current trend [7]. Subsequently, a question arises of how such sustainable production and distribution systems can be implemented where more and more attention is paid in the literature to the relationship between sustainable development of the economy and functioning of supply chains. In the Special Report on Climate Change and Land prepared by the Intergovernmental Panel on Climate Change, it is encouraging to note that consumption of locally produced food and efficiency of food processing/transportation results in minimization of food losses, enhanced food security, and reduced greenhouse gas (GHG) emissions [8]. Other studies show that increased local production minimizes GHG emissions [9] and local food self-sufficiency relates to climate change, diets, and urbanization [10]. An interesting study on the concept of local self-sufficiency is presented by Pradhan et al. (2014) [11].

In this context, it is worth mentioning that an increasing number of consumers are looking for alternative sources of food produced near their place of residence [12,13]. These relatively new forms of organized food distribution are captured under the term Short Food Supply Chains (SFSCs). 
The dissemination of SFSCs in recent years can be linked to the preferences of consumers that search for high quality products. These trends are confirmed by numerous studies [10,14-17], showing that the growing popularity of short supply chains should be attributed to the distribution model based on local and fresh products. In addition, SFFCs can be seen as supporting sustainable and healthy farming methods and generating resilient farm-based livelihoods [18]. It is observed that SFSCs have the potential to improve farm incomes, promote sustainable farming systems, and contribute to local economic development.

As shown, research conducted on shortening food supply chains or short food supply chains [8-12,16,19] are focused on their sustainable potential; nevertheless, the studies take into consideration only one aspect or one pillar of sustainability, e.g. social $[12,16]$ or environmental, mainly GHG emissions [8-10]. Based on the research conducted in the literature, the research team highlights that there are knowledge gaps in characterizing the short food supply chains in connection with their sustainable potential, i.e. under three pillars of sustainability: economic, social, and environmental perspectives. The paper attempts to show the potential of SFSCs in all three perspectives of sustainability. The research was based on good practices, which were identified on the basis of criteria presented in Section 3.2. The criteria cover economic, environmental, and social sustainability. The next step of the research will be to create qualitative metrics for assessing the sustainable potential of SFSCs.

The paper is divided into three sections. In Section 2, the Materials and Methods are described. In Section 3, the typology of short food supply chains is presented and hot topics of analysis of short food supply chains are introduced. As a next step, the positive impact of SFSCs in three dimensions of sustainable development are analyzed. In addition, short food supply chains' good practices with an orientation on sustainability, are systematized, summarized, and analyzed. Finally, in Section 4, the discussion on possible barriers and chances for development of SFSCs is presented. The concluding remarks are given in the last section.

\section{Materials and Methods}

One of the key drivers of this research is to deliver information and knowledge, essentially through two complementary approaches.

The first part of the research assumed the systematization of information and data on good practices for SFSCs across Europe. The research was aimed at running a comprehensive scouting of good practices across Europe, resulting in over 100 good practices in total. The repository of good practices can be found at a dedicated place on the Short Supply Chain Knowledge and Innovation Network (SKIN) website [20]. These were identified through extensive mapping in different European countries on the basis of harmonized methodology and metrics on what a good practice is in terms of results, sustainability aspects, and its socio-economic impact on territories, as well as its replicability potential. These methodology and metrics were discussed and prepared by the consortium of the SKIN project (among others, most of the authors of this paper) and experts invited to the consortium meeting. The Delphi method was used for preparing the methodology and metrics (criteria for organizing and analyzing of case studies). The Delphi method belongs to the group of heuristic methods in which the knowledge, experience, and opinions of experts in a given field are used. The research consists of conducting a series of surveys among experts. The stages of the research in the Delphi method include defining the problem, selecting a group of experts, preparation of the survey, analysis of feedback responses, and development of results.

The case studies (material for this research) being analyzed in the paper were collected according to indicated methodology, among others, by most of the authors within the framework of the EU Horizon 2020 project SKIN-Short supply chain Knowledge and Innovation Network. Most authors of the paper were the main contributors in this project.

The criteria (hot topics) were used to thematically organize good practices according to interesting and relatable themes for end users (criteria are described in Section 3.2.). The detailed structure of hot topics can be found on the SKIN website [20]. The repository of good practices is available for each 
interested researcher. A similar study, as provided within the framework of this paper or a study with another focus, e.g. governance, might be conducted. One of the hot topics was Values, describing three pillars of sustainability, i.e., social, economic, and environmental aspects. Subcategories in the hot topic of Values, as shown in Table 1, cover the areas of economic, environmental, and social sustainability.

The second part of the research assumed pointing to the positive impact of SFSCs in three dimensions of sustainable development. The SFSCs and their development were main themes of six "innovation challenges workshops". The workshops allowed stakeholders to propose ideas for SFSC development in areas like sustainability, consumers, logistics and distribution, and regulations. During the workshops, the producers (participants of SFSCs) were interviewed in the context of the positive impact of SFSCs on sustainability; the experts were sharing opinions on this topic and the survey on discussed areas was also conducted. Based on the collected knowledge, areas of the positive impact of SFSCs in three dimensions of sustainable development were prepared.

The literature review was also done to address key issues related to SFSCs (based on Google Scholar and Scopus where key words were used to search such as short food supply chains, sustainability, social, economic, environment. All agricultural systems were included in this search).

An additional section on success factors and barriers to SFSC $s^{\prime}$ creation and function was included in the paper. The success factors and barriers were identified based on good practices collected within the research. The purpose of including this section was to provide a broader perspective in the discussion on the sustainability of SFSCs. The success factors and barriers are introduced in Section 4 of this paper.

\section{Results}

\subsection{Typology of Short Food Supply Chains}

In the literature, one can find various definitions of SFSCs. The "Short Supply Chain" is often used as an umbrella concept [15].

The concept assumes context-dependent economic, socio-cultural, policy, organizational characteristics, and having different impacts on local economies. The definitions of short supply chain are formulated under different criteria, such as the number of intermediaries, physical distance, social relations, knowledge exchange, locality, and governance involvement. There are many different forms of SFSCs in Europe, however, they share a common characteristic of reduced numbers of intermediaries between the farmer or food producer, and the consumer. The number of intermediaries is often indicated as a discriminating factor to define SFCS. In the definition proposed in the European rural development regulation (1305/2013), one also notes a reference to a limited number of economic operators. This reference is also seen in the definition proposed by Parker [21], wherein the possibility of the absence of intermediaries in the supply chain is indicated. According to the regulation, a short supply chain means a supply chain committed to co-operation, improving local economic development, and that is also characterized by short geographical distance between the producer and the consumer, and close social relations between producers, processors, and consumers [19].

Taking into account the criteria for SFSCs, a variety of classifications or typologies were developed with the purpose of their systematic exploration. The typologies are also useful for implementation of necessary support measures [22]. Three main types of short food chains on the basis of the number of intermediaries, physical distance, and organizational arrangements were proposed within the European Commission IMPACT project $[15,16]$. The conducted research allowed for a distinction of face-to-face, proximate, and spatially extended SFSCs. According to Mundubat [23], SFSCs can be classified into nine categories, as shown in Figure 1, on the basis of the low, medium, and high levels of compromise adopted either by consumers or producers. 


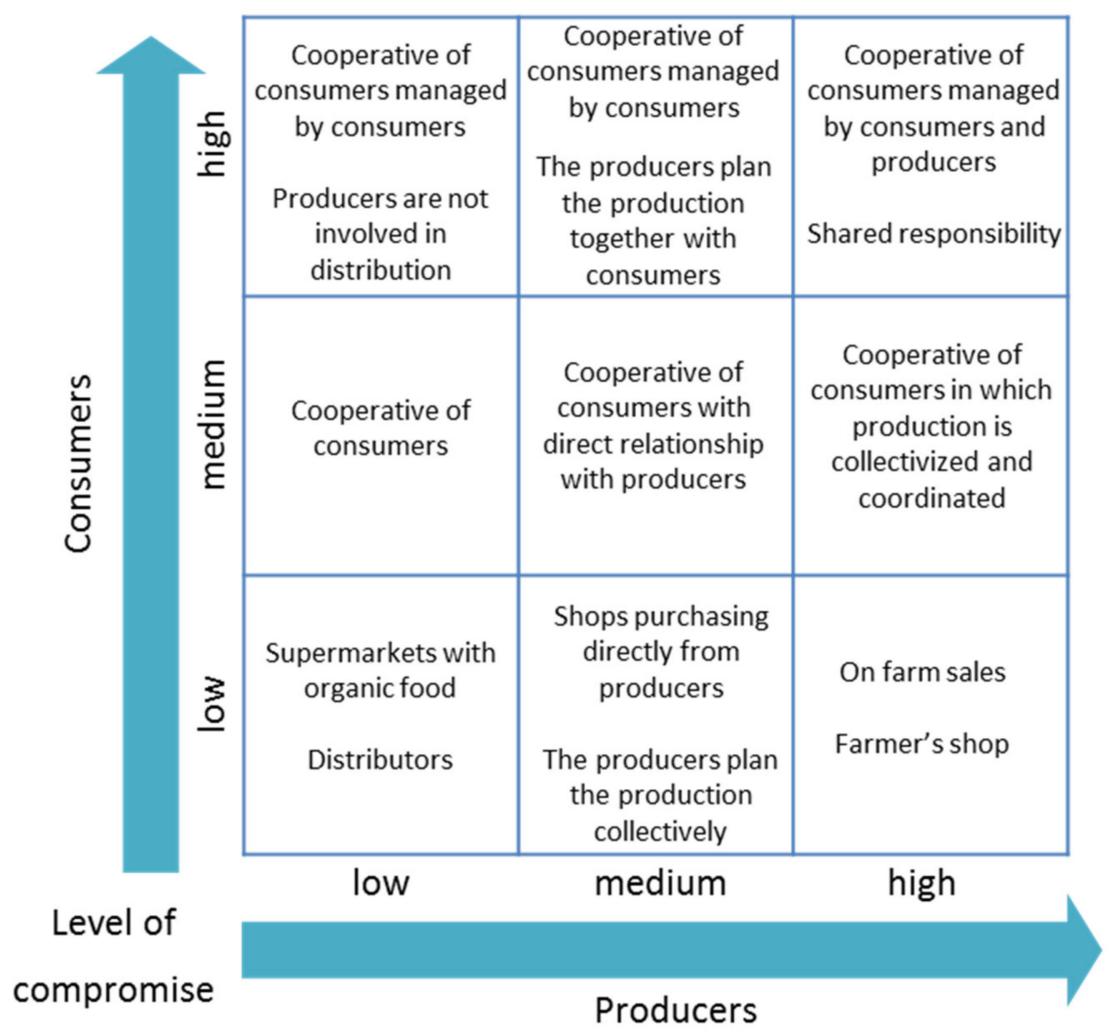

Figure 1. A typology of SFSCs based on the level of compromise adopted by consumers or producers. Source: Own evaluation based on Mundubat [23].

Within another typology (the CROC project [24]), SFSCs were divided into direct/indirect (with one intermediary), and individual/collective. Whereas three types of SFSCs, namely direct sales by individuals, collective direct sales, and partnerships of producers and consumers, were distinguished on the basis of individual or collective initiators of SFSCs [23].

Based on the knowledge gathered by the authors within the framework of the SKIN project, we distinguish also SFSCs functioning as local food systems, hyper-local food systems, and ultra-local food systems.

The most traditional meaning of SFSCs includes actors functioning in local food systems, usually located in rural areas not far from a major town or city, that aim to grow their revenues by also operating as a processor and a retailer. Very often these actors have been the pioneers of holistic and sustainable farming and production methods, including the organic food movement. Their shops often sold food at a premium on the basis that it was better, being more natural and good for the environment. Consumers also appreciated knowing where goods came from, being able to visit the farm, and get closer to nature and its cycle of seasons. Nevertheless, many of these practices have since been copied by large producers and all big retailers have started to sell organic products. Many of these actors source their product from local producers, and many have adopted policies that favor producers that employ good production methods, such as grass fed beef and free-range eggs and pesticide-free fruit and vegetables. The meaning of local food systems might be extended to the concept of local self-sufficiency [11]. Pradhan et al. (2014) presented the potential of a region to be self-sufficient, which could be achieved by focusing agricultural practices to meet local and regional demands, and by shifting dietary choices toward local and regional products [11].

The hyper-local food systems include SFSCs usually located in rural areas not far from the city, and usually involved in production, processing, and vending. The bigger picture includes traditional urban farming activities for the production of fresh fruit and vegetables that have been intensified 
thanks to technology. It also includes new initiatives based on bioreactors (breweries) producing among others meat and leather substitutes and can be considered as part of the circular bio-economy.

The ultra-local food systems cover gardens grown as a hobby. In many cases, this activity provides actors with quantities of food they grow themselves, to eat at home, share with neighbors, or sell in small markets. Cities and towns often encourage this at times as a measure for food security, but also as a way to enrich community living by encouraging contact among neighbors.

\subsection{Hot Topics while Analyzing SFSCs}

While analyzing SFSCs, the four main topics of interest were identified. The classification of topics was indicated based on the results of six workshops conducted within the SKIN project. The identified groups were used for classification of good practices in SFSCs. The topics were divided as follows, and as shown in Figure 2:

- Products;

- Organizational/institutional/systems;

- Governance;

- Sales.
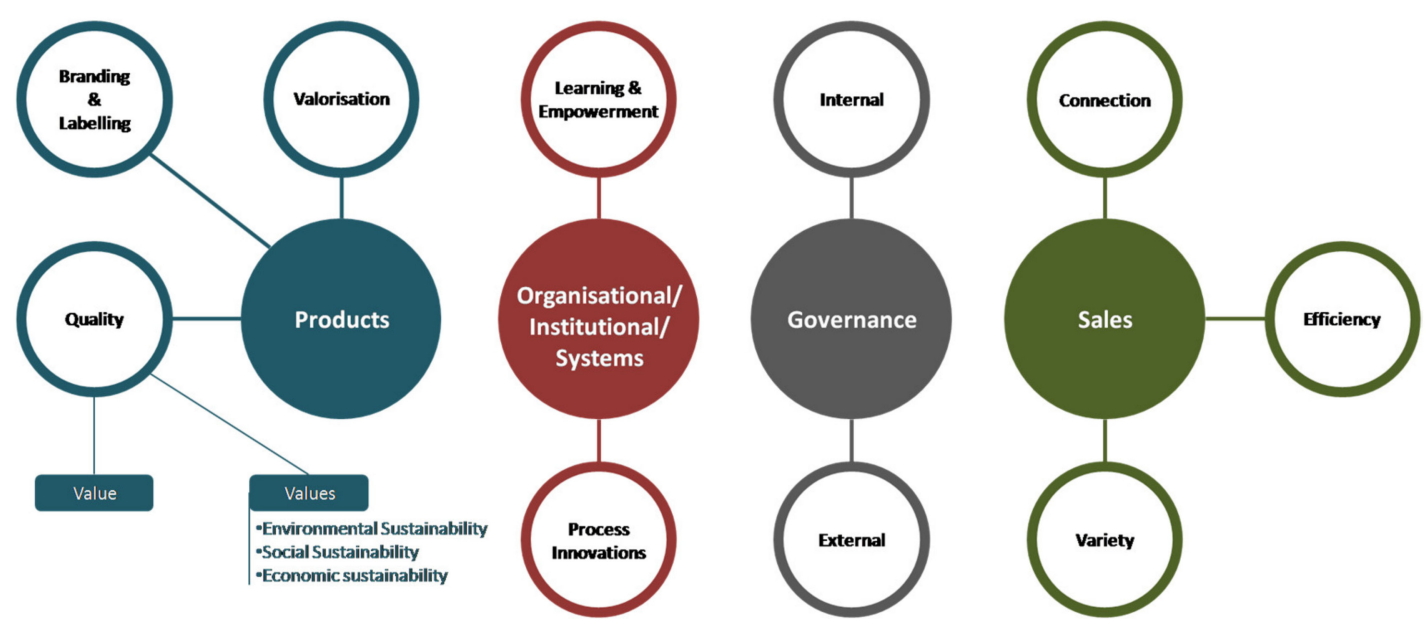

Figure 2. Hot topics in analyzed SFSCs.; Source: Results of workshops conducted within SKIN project.

The main topic is connected to Products. Within the first group (products), topics connected to the following areas were included:

- Branding and Labelling (describing innovations in communicating to consumers product characteristics or product range);

- Valorization (describing innovations in products, product range, or novel approaches to product development, e.g. multi actor design, co-design);

- Value (describing healthiness, nutritional value, freshness, and taste);

- Values (describing three pillars of sustainability, i.e. social, economic, and environmental aspects). The area of Values is presented in Table 1. 
Table 1. Criteria of economic, environmental, and social sustainability within the SKIN project.

\begin{tabular}{c|c}
\hline \multicolumn{1}{c}{ Areas } & Criteria \\
\hline Economic Sustainability & $\begin{array}{c}\text { Profitability } \\
\text { Generating local employment } \\
\text { Reduced economic uncertainties } \\
\text { Training and coaching initiatives } \\
\text { Synergies with other sectors }\end{array}$ \\
Environmental Sustainability & Markets/events/initiative for multiple producers locally \\
& Preservation and valorization of small farms \\
\hline Social Sustainability & GHG emissions \\
& Energy use and carbon footprint \\
& Ecological soundness of production methods \\
& Food miles \\
& Food waste \\
\hline & Connection between producers and consumers \\
& Trust, sense of community \\
& Community pride and animation \\
& Recognition of producers \\
& Consumer empowerment \\
& Well-being \\
\hline
\end{tabular}

Source: The Authors.

Within the Organizational/Institutional/Systems, two aspects were identified, i.e., Learning and Empowerment (networking, cross-learning), and Process Innovations, in relation to collaboration within the area of logistics and distribution. The topic of Governance covers Internal and External aspects. The Internal part touches agreements between chain partners and decision-making structures. The External part includes enabling government policies and regulatory frameworks, and tenders for public procurement with social and environmental criteria.

The topic of Sales covers Efficiency (effective ordering systems, physical distance to consumers, reliable distribution), Variety (bringing together supplies from many small producers through collaborative hubs), and Connection (events for consumers, e.g., "meet the farmer", use of social media etc.).

\subsection{Sustainable Development in Supply Chains}

The achievement of economic, social, and environmental success in a company is crucial for finding the way to a sustainable and profitable future facing environmental and social challenges. Current analyses indicate that human activity has exceeded the carrying capacity of earth's resources. Remediation efforts through technological advancement and conservation may extend the overall ability of earth's resources to sustain humanity. However, a "business as usual" approach to the problem will ensure that future generations are much worse off compared to the current situation.

In the last twenty years, the issue of sustainability has become mainstream in supply chain management research and it is now an area of significant research activity. In particular, much research has been devoted to SFSCs too. The sustainability aspects here play a significant role in connection with the consumer demand for quality and traceability, alarming health crises in food markets, increasing farm value-added (margin distribution), promoting sustainable farming systems, diversifying production, and contributing to local economic development. A potential positive impact of SFSCs on the three dimensions of sustainable development is indicated in Table 2. 
Table 2. Positive impact of SFSCs in the three dimensions of sustainable development.

\begin{tabular}{|c|c|c|}
\hline Economic Impact & Social Impact & Environmental Impact \\
\hline $\begin{array}{l}\text { - } \quad \text { Reduction of farmers' } \\
\text { economic uncertainties. } \\
\text { - } \quad \begin{array}{l}\text { Support the profitability of } \\
\text { small and medium farms. }\end{array} \\
\text { - } \quad \begin{array}{l}\text { Increase the re-circulation of } \\
\text { community income. }\end{array} \\
\text { - Creation of new jobs in rural } \\
\text { areas (generating local } \\
\text { employment). } \\
\text { - } \quad \begin{array}{l}\text { Decrease of production costs } \\
\text { and market price. }\end{array} \\
\text { - Improving synergies with } \\
\text { other sectors. } \\
\text { Increase of food } \\
\text { production quality. } \\
\text { Contribution to European } \\
\text { food safety. }\end{array}$ & 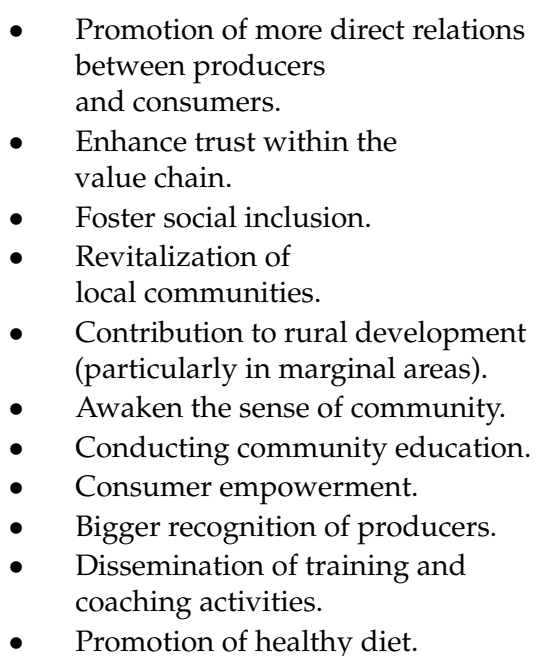 & 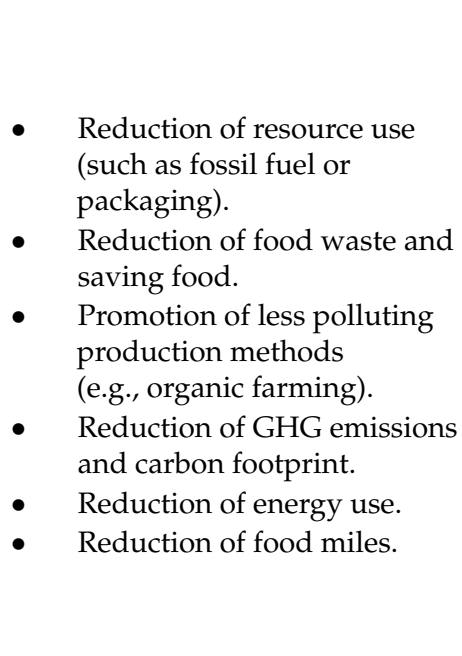 \\
\hline
\end{tabular}

Source: Own work based on the results of workshops conducted within the SKIN project.

The main conclusion is that SFSCs help to promote and to enable the driving of sustainable farming systems. The first dimension focuses on economic aspects. Generally, SFSCs contribute to local economic development, in particular, the impact of SFSCs covers the potential to increase farm value-added (better profit allocation), to decrease uncertainty, and to diversify product range. The social impact includes development of local social networks and increasing trust within the food chain, mainly consumers' trust in the process and product quality. Within the environmental area, it is assumed that small-scale production entities, like participants of SFSCs, cause less pollution than big food producers.

It is worth mentioning that cooperation within SFSCs can help to integrate new participants in the chain within the agri-food sector. There are many benefits to be gained from engaging in collaborative activities while creating short supply chains [18]: higher margins/lower overheads, improved product range, resource sharing, local food chain infrastructure, increased negotiating power, and mutual support through collaboration.

As noted in Table 2, some beneficial effects on the environment, economy, and society may be noticed while shortening the supply chain. Nevertheless, not all short chains have the expected positive impacts on the system. Here, the way in which the supply chain is shortened is important. In addition, creating short supply chains reflects market failure as: information asymmetry, transaction costs, uncertainty, opportunism and lack of confidence, economies of scale, external effects, social inequality, and information (knowledge) flow. The limitation of functional weaknesses of the market through creation of short supply chains may relate to three sustainability aspects. The relationships that occur in each group indicate the following relations:

- Environmental aspects

- The reduction of information asymmetry regarding products and processes. As a consequence of the reduction of information asymmetry, one may achieve more responsible exploration of natural resources like water, land, and air.

- The reduction of external effects regarding products and processes. As a result, we may achieve a reduction of emissions to the environment; that is, sewage to the water, fertilizers to the soil, gas emissions to the air. A significant impact on the environment can be exerted throughout the product life cycle, including transportation and operations of logistics contractors. 
- $\quad$ Economic aspects

- The reduction of transaction costs between participants of supply chains through better coordination and shortening of value creation.

- The reduction of uncertainty, opportunism, and lack of confidence between participants of supply chains. This may emanate from better coordination and communication between market participants and the reduction of resources involved in control and risk assessment.

- The reduction of information asymmetry regarding products and processes. As a consequence of the reduction, one may achieve a fair contract, transparency in establishing business networks, and prevention of corruption.

- Social aspects

- The reduction of social inequality and information (knowledge) flow between supply chain participants that create value to customers and the society. Thanks to a better exchange of information about products and processes, including resources involved in their creation, one may achieve the reduction of social inequality and information flow.

- The reduction of information asymmetry regarding products and processes. As a consequence, one may introduce fair employment practices, cooperation with local communities, respect, and principles of equality among employees.

\subsection{Good Practices Within SFSCs—Orientation on Sustainability}

As was mentioned in the previous part of the paper, many types of short supply chains may be distinguished. We observe also the increasing number of SFSC initiatives all over the world, in particular in Europe. These SFSCs could be seen as a relatively new crucial direction of food production and distribution on a bigger scale. Thus, further research is needed. The assessment of SFSC initiatives through good practices is a recognized tool of research. The identification and the synthesis of good practices was done within the framework of the SKIN project, Horizon 2020. Over 100 examples of such chains in 15 European countries were identified, described, and analyzed. In Figure 3, the structure of identified SFSC practices by country and sector is presented.

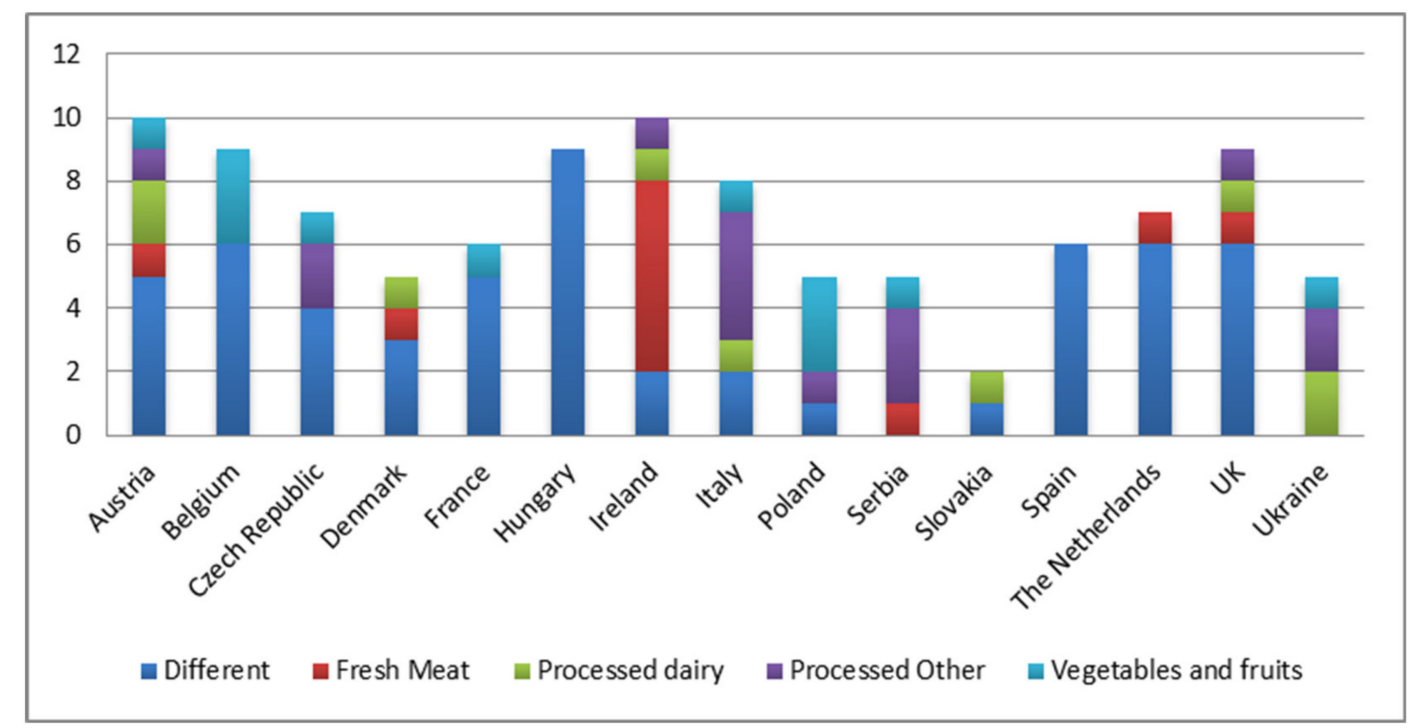

Figure 3. SFSC good practices by country and sector. Source. Own elaboration based on SKIN project.

The highest number of identified practices was recognized in Ireland, Austria, UK, and Hungary. The analyzed good practices were identified in sectors like fresh meat, processed dairy, and vegetables and fruit. In Poland, the majority of the practices related to the fruit and vegetable sector, while 
in Ireland, the meat sector was most popular. Nevertheless, a tendency to include more than one agri-food sector within a single enterprise was observed in the sample. Good practices cover specific distribution channels, such as on-line sales with home delivery, collection at designated places, or inviting consumers to farms. Almost all (about 90 cases) of the analyzed good practices were connected to the first level of agricultural production. Almost 40 of them were focused on processing and retailing. Some of the identified cases were connected to tourism providers, labs, or wholesalers, as shown in Figure 4. The analysis showed that different sectors' participants and supply chain stages are interested in activity within the short chain. Many of the participants see the potential and benefits of shortening the path to the consumer. It is of high importance that this development follows the concept of sustainability, which relates to the maintenance and enhancement of environmental, social, and economic resources. The possible impacts and benefits of such initiatives were analyzed within the three dimensions of sustainability, as shown in Figure 5. The research was based on case studies/good practices collected within the SKIN project, Horizon 2020.

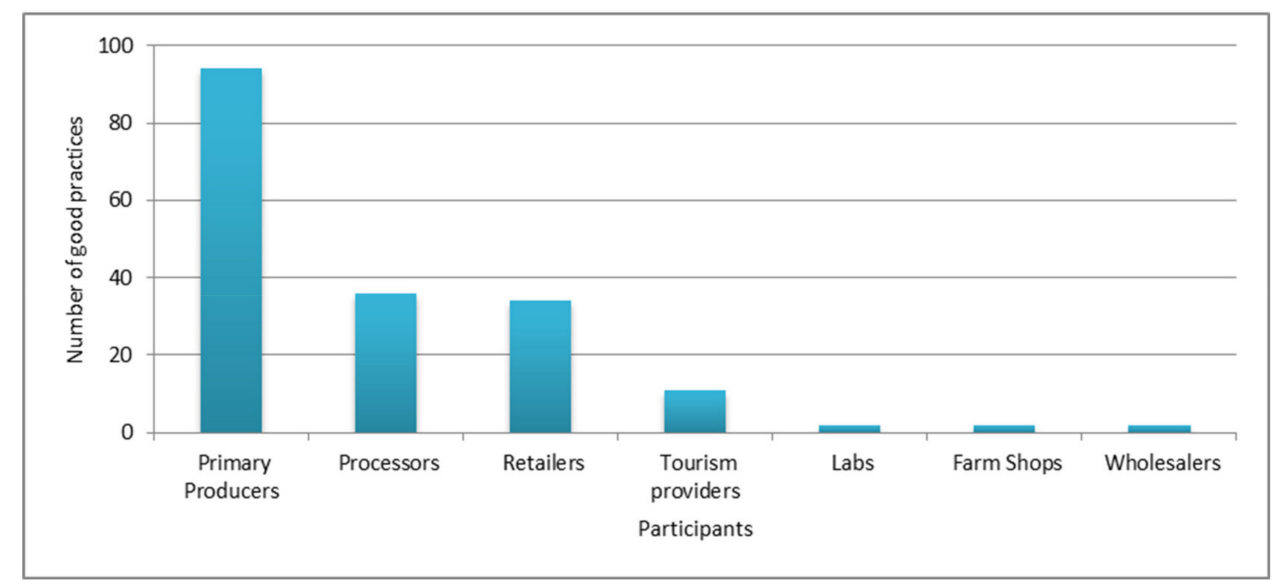

Figure 4. Participants of SFSC good practices; Source: Own elaboration based on SKIN project.
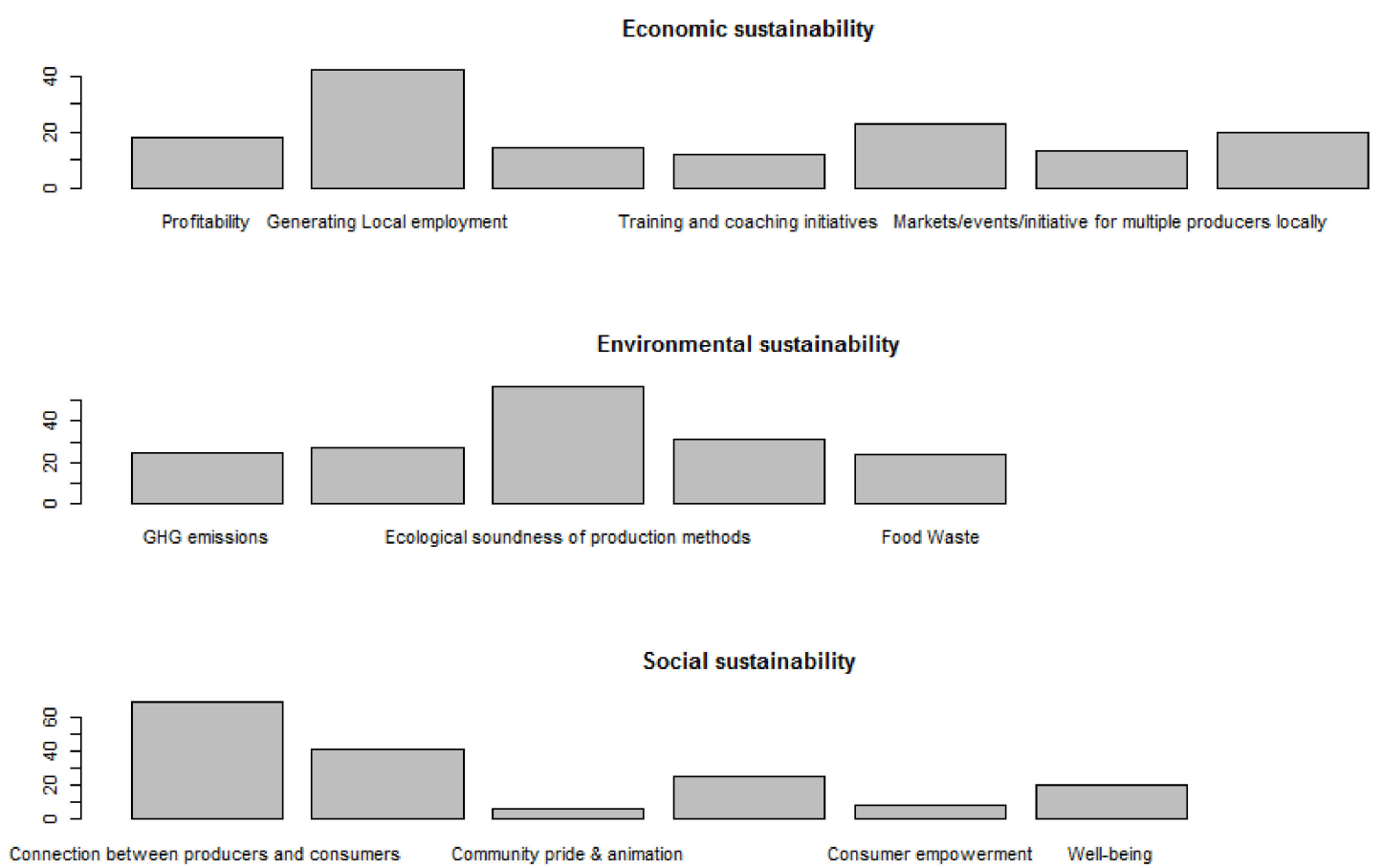

Figure 5. SFSC good practices within sustainability dimensions. Source: Own elaboration based on SKIN project. 
It is obvious that the main goal of each economic activity on the market is profit oriented. Nevertheless, the additional economic benefits of SFSCs are, among others, generating local employment (42 case studies), supporting synergies with other sectors (23 case studies), preserving and valorizing small farms (20 case studies), reducing economic uncertainties (14 case studies), supporting local initiatives for multiple producers (13 case studies), and training and coaching initiatives (12 case studies). Such supply chains can also be seen as a means to restructure the sector in order to develop sustainable farming methods. The environmental dimension is supported by ecological production methods (57 case studies), and decreasing food miles (31 case studies), less energy use and carbon footprint (27 case studies), less GHG emissions ( 25 case studies), and reduced food waste ( 24 case studies). Additionally, there is a very strong side of SFSCs, i.e. the social dimensions, with benefits such as strengthened connections between producers and consumers (69 case studies), increasing trust and sense of community (41 case studies), increasing recognition of producers ( 25 case studies), and community pride and animation (6 case studies).

Based on the analysis, one can deduct that SFSCs as local structures fulfill the concept of sustainability within all three dimensions, which gives the stimulus to multifunctionality in agriculture, satisfying the needs of both the consumption and production side. The direct relationship between the producer and the consumer allows transfer of knowledge between them.

\section{Discussion on Possible Barriers and Chances for Development of SFSCs}

In the previous section of the paper, we have shown that SFSCs are part of the concept of sustainable development. Thus, there is a strong need for creation of such initiatives. Nevertheless, development of the short supply chains may be more stable by overcoming the barriers and using success factors. Taking into account the outcomes from the case studies, the barriers and success factors were identified in Table 3. In general, the entities functioning within the SFSCs face barriers mainly of economic nature.

Table 3. Main factors of success and barriers.

\begin{tabular}{cll}
\hline \multicolumn{1}{c}{ Area } & \multicolumn{1}{c}{ Success Factors } & \multicolumn{1}{c}{ Barriers } \\
\hline \multirow{2}{*}{ Creation of SFSCs } & Product know-how and innovation & $\begin{array}{l}\text { Difficulties in securing the finance needed to } \\
\text { invest in new technology }\end{array}$ \\
\cline { 2 - 3 } & Cross-learning between stakeholders & $\begin{array}{l}\text { Need 'expert' advice, concentrated on a } \\
\text { small-scale collaborative models }\end{array}$ \\
\cline { 2 - 3 } & $\begin{array}{l}\text { Enabling regulatory frameworks and } \\
\text { government policies }\end{array}$ & $\begin{array}{l}\text { Disabling regulatory frameworks and } \\
\text { government policies }\end{array}$ \\
\cline { 2 - 3 } Product development & $\begin{array}{l}\text { Availability of specialized local business and } \\
\text { organizational support }\end{array}$ & $\begin{array}{l}\text { Local organizations and local authorities are } \\
\text { not always skilled in providing business and } \\
\text { support specifically for collaborative ventures }\end{array}$ \\
\hline & $\begin{array}{l}\text { New and improved products can be } \\
\text { developed through application of technology; } \\
\text { efficient }\end{array}$ & $\begin{array}{l}\text { Investment of time and money is needed for technology adoption } \\
\text { product development }\end{array}$ \\
\cline { 2 - 3 } & $\begin{array}{l}\text { Banks and institutions are often reluctant to } \\
\text { invest in collaborative SFCs because of the } \\
\text { high level of risk }\end{array}$ \\
\hline $\begin{array}{l}\text { Technological innovations and appropriate } \\
\text { management }\end{array}$ & $\begin{array}{l}\text { Lack of specialized knowledge such as IT and } \\
\text { accountancy skills }\end{array}$ \\
\hline Collective branding & $\begin{array}{l}\text { Lack of expertise in branding; time needed to } \\
\text { develop collective vision, cost }\end{array}$ \\
\hline
\end{tabular}


Table 3. Cont.

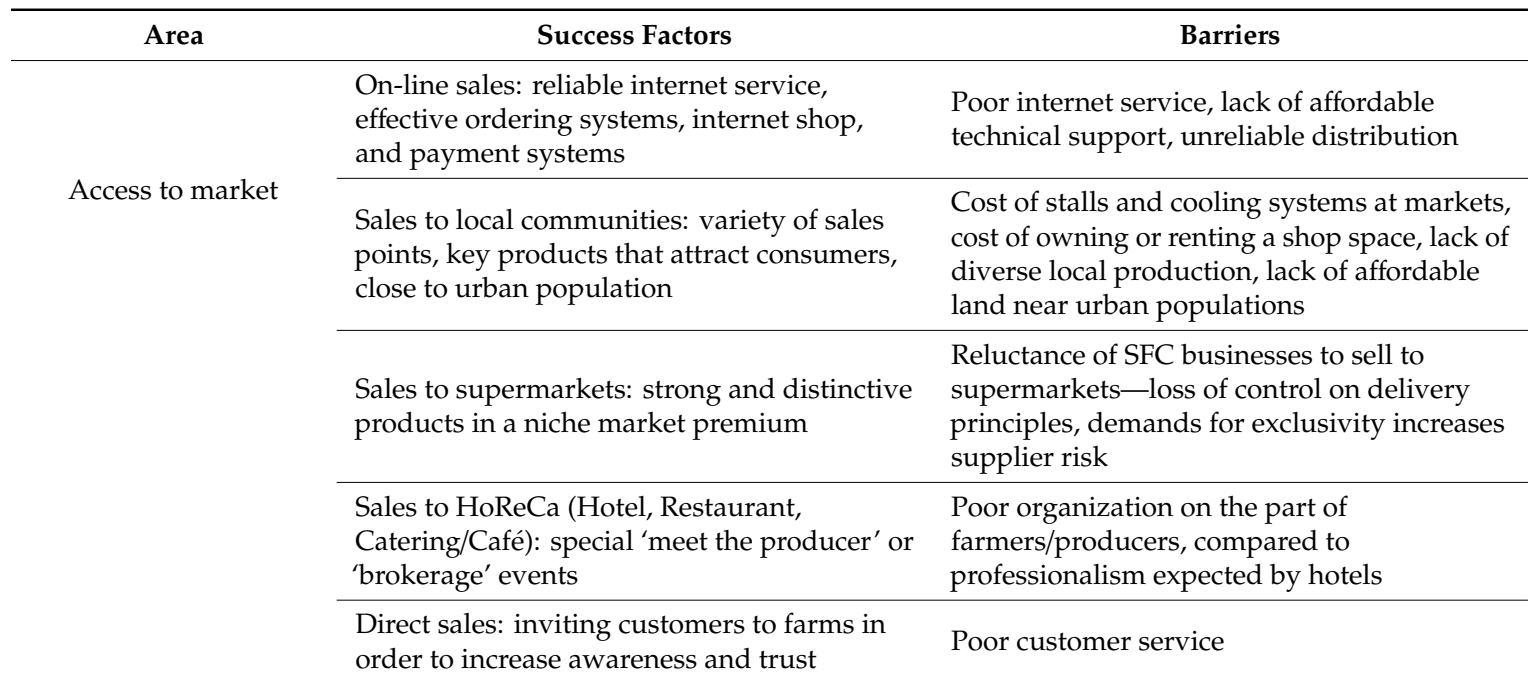

Source: Own elaboration.

Actors involved in the creation of short supply chains have to deal with three main areas that can both contribute to the initiatives' success and can be barriers during the creation process, i.e., regulations, competences, and access to financing. National or EU regulations (mainly EU hygiene rules are a serious challenge to small and traditional food producers) as well as tax systems are in some countries an obstacle to the development of cooperation within short supply chains.

It is true that a short supply chain can arise thanks to a small investment. On the other hand, limited access to technology and equipment creates the need for increased funding to develop innovation. Lack of appropriate skills can be a serious challenge for creating short supply chains, but this does not mean that all actors involved in this process have low qualifications. Rather, it is about how to get or share skills. Although short supply chain practices are becoming increasingly common across Europe, their impact on economic sustainability seems limited by lack of experience and knowledge, which hinders the dissemination of this distribution model and the dissemination of innovation.

Product development is important for every food industry. Nevertheless, investment in new product categories and technological innovations requires time and money. In the case of short agri-food chains which are based on cooperation, the development of products is not only closely related to the type of product, but also to the structure of the chain and the values that connect the cooperating entities, including the consumer. It should be also remembered that for the majority of buyers, price is a key determinant of purchase decisions. Taking into account market conditions, one should notice that producers from short supply chains compete with low-cost, industrial, large-scale actors.

Regarding access to markets and consumers, the general recommendation is that actors involved in short supply chains understand better how consumers' lifestyles affect purchasing food. Training that helps individuals involved in short chains to access more information about consumer trends is very valuable. Nevertheless, access to market research is very difficult for small-scale entities. In this area, a cooperation with universities and research centers can be helpful. It is also important to notice that different product categories require different approaches and that different locations have different dynamics for agri-food chains.

Based on the success factors and barriers identified above, it should be remembered that short supply chains of agri-food products are very diverse in terms of their structure. Any measures supporting cooperation in these initiatives will therefore have to take into account the organizational structure, objectives, and activities of the chain. 


\section{Conclusions}

The Short Food Supply Chain (SFSC) is a developing model functioning in parallel to conventional food chains. It becomes an alternative to globalized agri-food networks. Nowadays, an increasing number of entities functioning within short food chains is noticeable. The increase of short supply chains is someway directly related to the growing importance of food quality from both the production and the consumption side. In addition, the benefits of SFSCs support the sustainability concept. In general, short chains meet the societal demand of providing quality food while reducing the environmental impact of agriculture.

Within the framework of this paper, SFSCs were investigated based on the analysis of case studies/good practices [14]. Over 100 examples of such chains in 15 European countries were identified. The initiatives were analyzed within the three dimensions of sustainable development. The economic benefits of SFSCs are, among others, generating local employment, supporting synergies with other sectors, and profitability. Such supply chains can also be seen as a means to restructure the sector in order to develop sustainable farming methods. The environmental dimension is supported by ecological production methods, the decrease of GHG emissions, food miles, energy use and carbon footprint, and food waste in comparison to conventional food chains. In addition, there is a very strong side of SFSCs, i.e. the social dimensions, with such benefits as strengthening the connection between producers and consumers, an increased trust and sense of community, and increased recognition of producers. Thus, SFSCs as local structures fulfill the concept of sustainability within all three dimensions, which give stimulus to multifunctionality in agriculture, satisfying the needs of both the consumption and production side.

We have shown that SFSCs are part of the concept of sustainable development. Thus, there is a strong need for creation of such initiatives. Nevertheless, development of the short supply chains may be more stable by overcoming the barriers and using success factors. In general, the entities functioning within the SFSCs have to face barriers mainly of economic nature.

Author Contributions: Conceptualization, S.J. and M.B.; methodology, S.J.; validation, S.J. and A.B.-J.; formal analysis, S.J. and M.B.; investigation, S.J.; writing-original draft preparation, S.J. and A.B.-J.; writing-review and editing, S.J. and A.B.-J.; visualization, S.J.; supervision, S.J. and M.B.; project administration, S.J.; funding acquisition, S.J. All authors have read and agreed to the published version of the manuscript.

Funding: Research granted by European Commission within the Horizon 2020 Programme as project no. 728055. "Short supply chain Knowledge and Innovation Network-SKIN".

Acknowledgments: The authors would like to thank the participants of the 3rd International Forum on Agri-Food Logistics Towards the Sustainability of Logistics in the Agri-Food Supply Chains for helpful comments. We are grateful to editors and the reviewers for insightful remarks and suggestions.

Conflicts of Interest: The authors declare no conflict of interest.

\section{References}

1. Jarzębowski, S. Integracja Łańcucha Dostaw Jako Element Ksztattowania Efektywności Sektora Przetwórstwa Rolno-Spożywczego [Integration of Food Supply Chain as an Element of Efficieny of Food Processing Industry]; Szkoła Główna Gospodarstwa Wiejskiego w Warszawie: Warsaw, Poland, 2013.

2. Lambert, D.M.; Cooper, M.C. Issues in supply chain management. Ind. Mark. Manag. 2000, $29,65-83$. [CrossRef]

3. Christopher, M. Logistics and Supply Chain Management: Strategies for Reducing Cost and Improving Service; Financial Times Pitman Publishing: London, UK, 1998.

4. Van der Vorst, J. Effective Food Supply Chains; Generating, Modelling and Evaluating Supply Chain Scenarios; Wageningen University: Wageningen, The Netherlands, 2000.

5. Hobbs, J.E.; Young, L.M. Closer vertical co-ordination in agri-food supply chains: A conceptual framework and some preliminary evidence. Supply Chain Manag. Int. J. 2000, 5, 131-143. [CrossRef]

6. Kashmania, R.; Keenan, C.; Wells, R. Corporate environmental leadership: Drivers, characteristics, and examples. Environ. Qual. Manag. 2010, 19, 1-20. [CrossRef] 
7. Tietenberg, T.L.; Lewis, L. Environmental \& Natural Resource Economics; Pearson Education: Boston, MA, USA, 2009.

8. IPCC Special Report on Climate Change and Land, Chapter 5 Food Security. Available online: https: //www.ipcc.ch/srccl/chapter/chapter-5/ (accessed on 20 April 2020).

9. Michalský, M.; Hooda, P.S. Greenhouse gas emissions of imported and locally produced fruit and vegetable commodities: A quantitative assessment. Environ. Sci. Policy 2015, 48, 32-43. [CrossRef]

10. Kriewald, S.; Pradhan, P.; Costa, L.; García Cantú Ros, A.; Kropp, J. Hungry cities: How local food self-sufficiency relates to climate change, diets, and urbanization. Environ. Res. Lett. 2019, 14, 1-9. [CrossRef]

11. Pradhan Lüdeke, M.K.; Reusser, D.E.; Kropp, J.P. Food Self-Sufficiency across Scales: How Local Can We Go? Environ. Sci. Technol. 2014, 48, 9463-9470. [CrossRef] [PubMed]

12. Cicia, G.; Cembalo, L.; Del Giudice, T. Consumer preferences and customer satisfaction analysis: A new method proposal. J. Food Prod. Mark. Taylor Francis 2010, 17, 79-90. [CrossRef]

13. Nie, C.; Zepeda, L. Lifestyle segmentation of US food shoppers to examine organic and local food consumption. Appetite 2011, 57, 28-37. [CrossRef] [PubMed]

14. Uribe, A.; Winham, D.; Wharton, C. Community supported agriculture membership in Arizona. An exploratory study of food and sustainability behaviours. Appetite 2012, 59, 431-436. [CrossRef] [PubMed]

15. Marsden, T.K.; Banks, J.; Bristow, G. Food supply chain approaches: Exploring their role in rural development. Sociol. Rural. 2000, 40, 424-438. [CrossRef]

16. Renting, H.; Marsden, T.K.; Banks, J. Understanding alternative food networks: Exploring the role of short food supply chains in rural development. Environ. Plan. 2003, 35, 393-411. [CrossRef]

17. Peters, R. Local Food and Short Supply Chains. EU Rural Rev. 2012. Available online: https://enrd.ec.europa. eu/sites/enrd/files/E8F24E08-0A45-F272-33FB-A6309E3AD601.pdf (accessed on 20 April 2020).

18. EIP-AGRI Report. 2015. Available online: https://ec.europa.eu/eip/agriculture/sites/agri-eip/files/eip-agri fg_innovative_food_supply_chain_management_final_report_2015_en.pdf (accessed on 2 March 2019).

19. Ilbery, B.; Maye, D. Alternative (shorter) food supply chains and specialist livestock products in the Scottish-English borders. Environ. Plan. 2005, 37, 823-844. [CrossRef]

20. SKIN, Horizon. 2020. Available online: http://www.shortfoodchain.eu/good-practices/ (accessed on 20 March 2020).

21. Parker, G. Sustainable Food? Teikei, Co-Operatives and Food Citizenship in Japan and in the UK, 2005. Working Paper in Real Estate and Planning: Reading, UK, 5 November 2005. Available online: http: //centaur.reading.ac.uk/21289/ (accessed on 20 March 2020).

22. Galli, F.; Brunori, G. Short Food Supply Chains as Drivers of Sustainable Development. Evidence Document Document Developed in the Framework of the FP7 Project FOODLINKS, 2013 (GA No.265287). Laboratorio di Studi Rurali Sismondi. Available online: https://orgprints.org/28858/1/evidence-document-sfsc-cop.pdf (accessed on 2 March 2019).

23. Mundubat. Circuitos Cortos de comercialización en Euskal Herria. 2012. Available online: http://pae.gencat.cat/web/.content/al_alimentacio/al01_pae/05_publicacions_material_referencia/ arxius/circuitoscortos_euskalherria.pdf (accessed on 2 March 2019).

24. Chaffotte, L.; Chiffoleau, Y. Vente directe et circuits courts: Évaluations, definitions et typologie, Les cahiers de l'observatoire, CROC, n 1, INRA, Montpellier. 2007. Available online: http://pm22100.net/docs/pdf/04_ CC_VD/130128_Cahier_de_1_Obs1-INTERNET.pdf (accessed on 2 March 2019).

(C) 2020 by the authors. Licensee MDPI, Basel, Switzerland. This article is an open access article distributed under the terms and conditions of the Creative Commons Attribution (CC BY) license (http://creativecommons.org/licenses/by/4.0/). 